University of Windsor

Scholarship at UWindsor

2012

\title{
An assessment of the early stages of a sustainable business model in the Canadian fast food industry
}

\author{
David Hutchinson \\ University of Windsor \\ Jang Singh \\ University of Windsor \\ Kent Walker \\ University of Windsor
}

Follow this and additional works at: https://scholar.uwindsor.ca/odettepub

Part of the Business Commons

\section{Recommended Citation}

Hutchinson, David; Singh, Jang; and Walker, Kent. (2012). An assessment of the early stages of a sustainable business model in the Canadian fast food industry. European Business Review, 24 (6), 519-531.

https://scholar.uwindsor.ca/odettepub/53

This Article is brought to you for free and open access by the Odette School of Business at Scholarship at UWindsor. It has been accepted for inclusion in Odette School of Business Publications by an authorized administrator of Scholarship at UWindsor. For more information, please contact scholarship@uwindsor.ca. 


\title{
In Press (October 2012) European Business Review http://www.europeanbusinessreview.com/
}

\section{An Assessment of the Early Stages of a Sustainable Business Model in the Canadian Fast Food Industry}

\author{
David Hutchinson, Ph.D. \\ Jang Singh, Ph.D. \\ Kent Walker, Ph.D. \\ Odette School of Business, University of Windsor
}

\section{Structured Abstract}

Purpose: The objective is to describe a Canadian corporation's implementation and application of a sustainable business operation and model. It is based upon a case study of an International Canadian coffee and donut chain: Tim Hortons.

Design/methodology/approach: Data were collected through: (1) extensive publications of corporate documents, (2) observations of actual operations at retail sites, (3) social media sites.

Findings: We find that Tim Hortons has clearly made progress toward greater sustainability. However, its program often lacks specificity, particularly in terms of greenhouse gas emissions. Within a visibly and highly polluting industry Tim Hortons sustainability program is a step in the right direction but there are areas in need of improvement.

Research limitations/implications: The findings of this study paradoxically suggest that it is difficult for a company in the fast food industry to truly become sustainable given certain characteristics of the industry (disposal food and beverage containers, and drive-thrus for example), yet sustainability is also imperative to business success and competitiveness.

Practical implications: Through a detailed examination of Tim Hortons' sustainable business approach we delineate a number of areas where the company can improve its sustainability. We also discuss areas of difficulty (e.g., drive-thrus) and areas in need of improvement (e.g., a detailed description of the sources of the company's greenhouse-gas emissions).

Social implications: Tim Hortons' sustainability program was only recently launched, and although the motivations behind the program are not discussed, it was not developed in response to any government subsidies or legislation.

Originality/value: Our main contributions are as follows. First, we methodically analyze the sustainable business approach of a Canadian fast-food company including but not limited to its value-added process, driving forces, and purchasing policies. This provides a beginning for others who wish to implement sustainability into an industry not known for its environmental responsibility. Second, we suggest ways that Tim Hortons could improve its sustainable business approach. Third, we provide a case study of how an iconic Canadian company with revenues over $\$ 2.5$ billion and nearly 4,000 stores across the globe has begun to implement sustainability into its core strategic approach. 
Keywords: sustainability, business model, fast food industry, recycling, composting, coffee, Canada

Paper type: Case Study from public documents 


\section{Introduction}

Environmental sustainability is now widely discussed and practiced in business, whether in business schools, non-profit organizations, government organizations, or corporations. A primary reason for the increased attention to the natural environment appears to be the increasingly dramatic human impact on the environment (Makower, 2009). For example, while there are natural causes of global warming, such as volcanic eruptions, it is now understood that the current warming is anthropogenic, that is, created by humans (Gore, 2006). Perhaps most concerning is that we have very little time to drastically change behaviours, and how organizations are run globally, if society hopes to avoid catastrophic events (Pacala and Socolow, 2004).

Since the industrial revolution business has been a major cause of environmental problems. Yet paradoxically, with a demonstrated lack of government action evident in the meeting of about 200 countries in Copenhagen 2009 (Svensson and Wagner, 2011a), it appears that real and rapid solutions will have to come from business. Indeed, a number of organizations have responded to the need for a more environmentally friendly business approach (e.g., Interface, The Body Shop, Patagonia). While the debate of whether environmental sustainability leads to improved corporate financial performance continues (Margolis and Walsh, 2003; Orlitzky, Schmidt and Rynes, 2003; Russo and Fouts, 1997), the reality is that a number of organizations, for a variety of reasons, have decided to engage in sustainable development (Margolis and Walsh, 2003).

The most commonly referenced definition of sustainable development comes from the World Commission on Environment and Development (1987, p.43) where it was defined as: "development that meets the needs of today's generation without compromising the ability of future generations to meet their own needs". Sustainability entails the successful integration of the economy, the environment, and society. The integration of these three elements has become so intertwined with corporate success that failure to consider their connection is a serious risk and potentially, if not likely, compromises the viability of any business (Mahler, 2007; Post, Preston and Sachs, 2002; Savitz and Weber, 2006).

Yet despite the importance of sustainability, as stated by Svensson and Wagner (2011a, p3): "Research in the field of business is...far from addressing core requirements and the multiple aspects of sustainable business operations and sustainable business models."

\section{$\underline{\text { Sustainable Business Operations and Sustainable Business Models }}$}

Tim Hortons is a well known and iconic Canadian fast food business whose large scale operations result in highly visible environmental impacts. To its credit it has embarked on a journey to reduce its carbon footprint but its program while ambitious has some apparent weaknesses.

The objective of this article is to describe and assess the early stages of a Canadian corporation's 'sustainable business operation and sustainable business model'. In so doing the article will 
highlight the impact of a sustainable business model on the retail efficiency and the challenges facing a powerful retailer in a competitive industry.

\section{$\underline{\text { Tim Hortons }}{ }^{\circledR}$ - A Canadian Café and Bake Shop Chain}

The current study describes a Canadian corporation's implementation and application of a sustainable business operation and model. It is based upon a case study of an International Canadian (originated) coffee and donut chain. Data were collected through: (1) extensive publications of corporate documents, (2) observations of actual operations at retail sites, and (3) social media sites.

The focal organization in this article is an international company originally incorporated in Canada, and presently considered a Canadian icon, called Tim Hortons Inc. Founded in 1964 in Hamilton, Ontario, Tim Hortons had humble beginnings selling coffee and donuts only. The restaurant was co-founded by a legend in the National Hockey League (NHL), Tim Horton, who quickly established a strong relationship with businessman Ron Joyce. Tim Horton himself died in a tragic car accident in 1974 and by 1975 as the sole owner of the company, Joyce had successfully expanded to 40 restaurants (timhortons.com). Following the roots of its founder, Tim Horton's continues to sponsor key strategic events, and has had particular success with its Timbits hockey campaign. Tim Hortons has been particularly effective at branding itself as a Canadian icon.

A key part of Tim Hortons' success has been its ability to change and develop along with consumer tastes. In 1976 Tim Hortons introduced Timbits (bite-sized donuts) which continue to occupy space on shelves across the country and now come in 35 different flavors (timhortons.com). Behind the wildly successful Timbits came numerous other product offerings including but not limited to muffins, cakes, pies, cookies, sandwiches, soups, and breakfast sandwiches, as Tim Hortons diversified its product mix to meet ever increasing consumer demand. Despite such product diversity coffee remains the number one seller at Tim Hortons (timhortons.com). With many 24-hour locations customers are sure to get their 'fix' regardless of the time, and an impressive $40 \%$ of customers visit a Tim Hortons four or more times per week (Hortons, 2010a).

With an eye to expansion into the U.S., Tim Hortons merged with Wendy's International Inc. in 1995, although it continued to operate as a separate entity. However, in 2006, under pressure from shareholders Tim Hortons conducted an initial public offering, and shortly after this

emerged as a separate entity (timhortons.com). Despite the separation from Wendy's, Tim Hortons continues to aggressively pursue growth in the U.S. Success in Canada came with a 95 percent franchise owned and operated business approach, and the same strategic expansion process is planned in the U.S (timhortons.com). While they have had some failures in the U.S., and in New England in particular, today, there are over 3,150 restaurants and kiosks across Canada and over 600 in the U.S (149 new stores opened in Canada and 96 in the U.S. in 2010 
alone), with 2010 revenues of over $\$ 2.5$ billion. In 2010, for the first time in Canadian restaurant history, they surpassed $\$ 5$ billion in franchised restaurant sales in Canada (Hortons, 2010a).

Today Tim Hortons is Canada's fourth-largest publicly-traded restaurant company by market capitalization, with a 41 percent share of "quick service restaurant traffic". Impressively, in both Canada and the U.S. they have demonstrated nearly two decades of overall continuous same-store sales growth (Annual Report, 2010). Recently, they have also begun to co-brand the regular Tim Hortons with Cold Stone Creamery restaurants (which primarily serves ice cream) opening both in one location, or independently from each other.

The published 2010 Sustainability \& Responsibility Report (Hortons ,2010b) indicates that the organization is in the second year, or early stages, of the implementation and application of the sustainability process, at a time when the subject of sustainability is generally seen as a necessity by major competitors in the marketplace. Tim Hortons Sustainability and Responsibility Policy suggests a vision of 'Making a True Difference ${ }^{\text {TM }}$ 'by being an active participant and partner for positive change in the world in regards to individuals, communities and the planet. The Sustainability Report suggests that the 'Sustainability and Responsibility Framework' is supported by stakeholders. The following will concentrate on the 'planet' aspect of the extensive policy.

\section{Findings: Tim Hortons Sustainability Business Operation and Model}

Using a model (see Figure 1) developed by Wagner and Svensson (2010) we examine the sustainable business approach of Tim Hortons, by investigating its (i) driving forces, (ii) purchasing policies, (iii) value-adding processes, (iv) intermediaries and transport, (v) retail practices, (vi) marketplace and, (vii) the natural environment in conjunction with Tim Hortons Inc's (THI) framework of individuals, communities and especially the planet as outlined in THI's 2010 Sustainability \& Responsibility Report (Hortons, 2010b).

\section{(i) Driving Forces}

The guiding principles of THI's sustainability policy are as follows: "1) Do things that make a true difference: 2) Acknowledge and respect the social, environmental and economic impact of our activities: 3) Honour, respect and support individuals and stakeholders: 4) Participate with, and build the success of, our communities: 5) Be honest and transparent in our communications" (Hortons, 2010b, p.3).

The company sees managing sustainability as a process involving the following four key focus areas: strategy development and the assessment of risks and opportunities; stakeholder engagement; materiality assessment; development of our commitments and goals" (Hortons, 2010 b, p.12).In their empirical investigation of the motivations behind sustainability, Bansal and Roth (2000) noted three basic motivations: competitiveness, legitimacy and ecological responsibility. Despite the Guiding Principles and the four key focus areas listed above, based on our analysis of THI we believe their motivations (driving forces) are based on competitiveness.

Evidence of the competitiveness motivation comes from the fact that most of THI's sustainability initiatives are related to reducing costs. For example, THI had improved their energy efficiency 
reducing their energy and water usage, resulting in reduced costs. As a more specific example, THI increased the weight of their coffee boxes from $20 \mathrm{lb}$. to $22.5 \mathrm{lb}$ resulting in an estimated 200 fewer truckloads per year (Hortons ,2010b). In addition, according to Bansal and Roth (2000) firms motivated by competitiveness pay particular attention to the cost-benefit analysis of sustainability, and make frequent use of words such as "cost". This is evidenced at THI by their modest ecological responsiveness (particularly in contrast to their major competitor: Starbucks), and their unwillingness to sacrifice profits for sustainability. This is most apparent in their continued reluctance to take any action with regard to their drive-thrus, which are widely considered to be harmful to the environment. Furthermore, a simple word count in THI's sustainability report found the word "cost" 16 times, compared to the word ecological (or ecology) which was never used. Lastly, consistent with a competitiveness motivation we found that THI was willing to incorporate sustainability only if it was perceived to enhance their financial performance.

Although there was also some evidence that THI was motivated by the need for legitimacy, given that such a need was driven by a perceived threat to long-term profitability, we believe this need is more closely related to a motivation of competitiveness. We also saw no evidence of actions based on regulatory pressure, and none of the keywords ("survival", "long-term sustainability", "license to operate") identified by Bansal and Roth (2000) for the legitimacy motivation were found in THI's sustainability report.

\section{(ii) Purchasing Policies}

The 2010 Sustainability Report indicates that sustainability has been embedded at the core team level of each business process (Hortons, 2010b, p76). Examples of their efforts in the purchasing area are outlined in the following.

In 2010 THI set a goal to provide assistance to 2,500 coffee partners (see Figure 2) to strengthen environmental management through education on sustainable "farming techniques such as recycling water, reducing pesticide usage, and promoting shade on the coffee farm" (Hortons, 2010 b, p55). THI reported that they were able to enroll 1,159, which almost doubled their efforts over a five year period.

The purchasing of "equipment, such as a dedicated fondant chiller, to reduce water demand and improve product consistency" (Hortons, 2010b, p66) assisted in reducing total water consumption from .60 to .51 liters per kilogram of production. They report that in all areas they are on target to a $5 \%$ decrease in water consumption. Interestingly, water consumption per full time corporate employee was reported to have increased approximately 50\% since the benchmark year 2008 (Hortons, 2010a).

Generally not considered when thinking about a coffee and donut shop, is a new Animal Welfare Policy and program which was implemented in 2011 to ensure that animal treatment within the supply chain is in accordance with industry guidelines (Hortons, 2011, p.74). It should be pointed out that THI purchases food products derived from farm animals, and are not directly involved in the raising, handling, transportation, slaughter, or processing of these animals. No performance was reported for this new goal. 


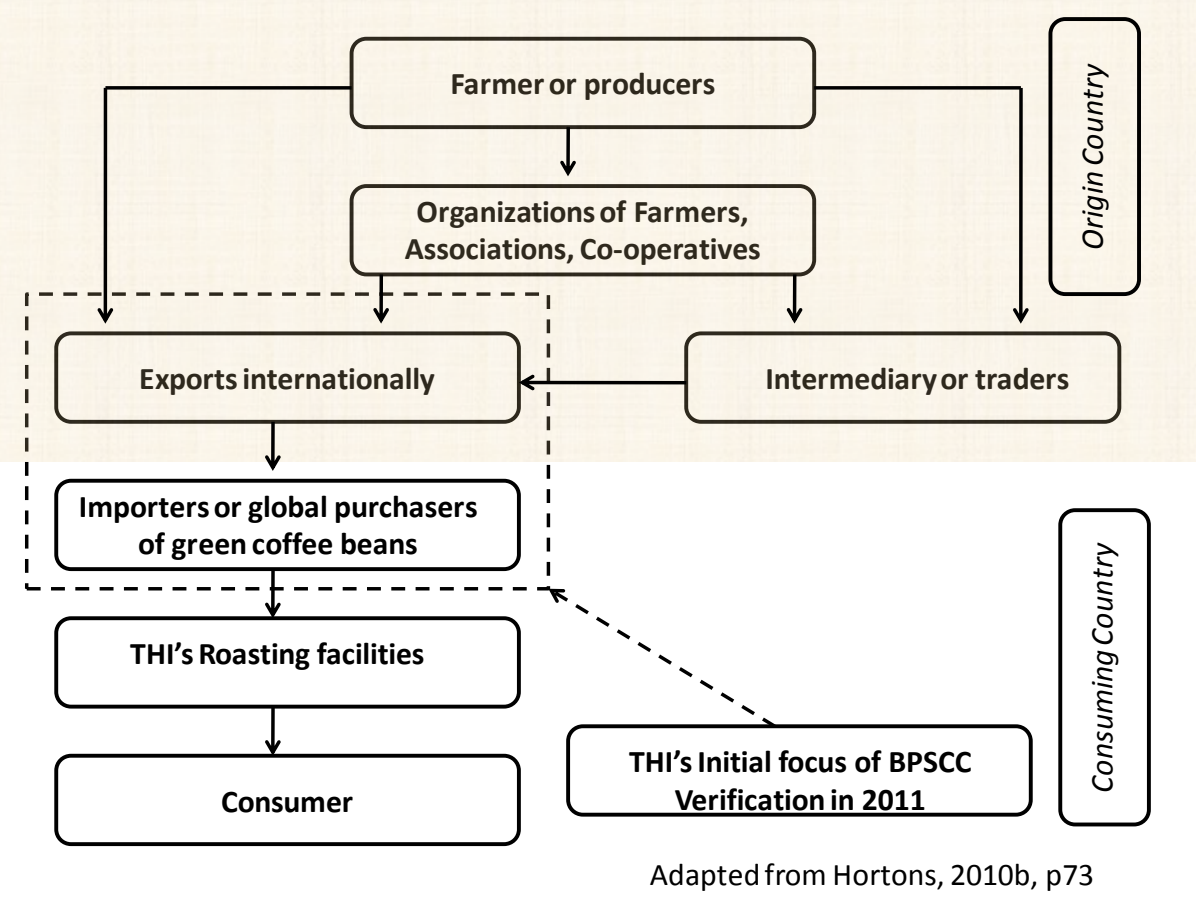

(iii) Value-adding Processes

Figure 2 Coffee Supply Chain

Tim Hortons cites continuous improvement initiatives for value-generating processes such as: new product innovation; new store construction and renovations; and supply chain processes. THI's sustainability initiatives are considered at the start of each new operational initiative, and then evaluated as part of the measurement of its success (Hortons, 2010b, p76).

Examples of the initiatives are as follows:

1. Reducing their energy, water and waste usage in various areas of operation. THI reports to be on target with a $5 \%$ reduction in these areas.

2. Equipping coffee roasting plants with catalytic afterburners, which prevent the aroma from disseminating into the air or surrounding community, resulting in $81 \%$ less gas versus older thermal afterburners. To minimize emissions roasters cycle the after burners while optimizing temperature, which reduces energy consumption by $6 \%$ and maintains environmental standards and the quality of the beans.

3. Installing more energy efficient (up to $30 \%$ ) variable-speed air compressors.

4. Purchasing high-efficiency industrial battery chargers for the forklifts.

5. Installing high-performance, energy-efficient lighting in the operations.

6. Changing the corrugated cardboard reduced freight costs and materials usage, resulting in 32 fewer shipments each year, $50 \%$ fewer back hauls with pallets and a $20 \%$ reduction in corrugated cardboard consumption annually.

In summary, a reduction of water, waste, natural gas and electricity are some of the initiatives. THI reported a 5\% reduction of water and energy, which was the goal, and a $2.58 \%$ reduction in fleet fuel efficiency where the goal was $5 \%$.

(Hortons, 2010b, p65-66). 


\section{(iv) Intermediaries and Transport}

Tim Hortons has a Supplier Code of Conduct -- a policy of being fair and ethical in their dealings with employees, restaurant owners, customers, and suppliers. Further, suppliers are encouraged to embrace the code of conduct in their organization and business dealings. The code was influenced by the International Labour Organization's core conventions as well as the Universal Declaration of Human Rights.

Supply chain and logistics initiatives reported by the company in the second year of program include evaluation of packaging material to ensure correct sizing, weight, and packing efficiency (Hortons, 2010b, p65). THI's goal is a 5\% reduction in packaging. THI has also indicated that it was working with vendors to upgrade pallet configurations and improve the efficiency of case content in-order to reduce logistic cost and energy usage. For example, by adding one additional pouch of bacon to a case with more efficient pallet configuration, 2,063 fewer pallets were needed and 79 fewer trucks. THI moved from $20 \mathrm{lb}$. coffee boxes to $22.5 \mathrm{lb}$. boxes, an action expected to save 200 truckloads per year (Hortons, 2010b, p65 \& p.68). Working with their supply partners, THI is testing the use of reusable plastic corrugated cases in lieu of corrugated cardboard for coffee distribution. The initiative is expected to reduce corrugated cardboard consumption, however, no specific goals or achievements were reported (Hortons, 2010b, p65).

At the THI distribution centres, energy savings of $25 \%$ on an intensity basis were achieved from 2008 to 2010 by:

1. Installing energy-efficient lighting and 150 motion sensors.

2. Modifying conveyors so they only operated when required.

3. Installing larger fans on ceilings to circulate heat and cooling thereby reducing gas consumption.

4. Installing variable-speed drives on some larger motors.

5. Installing on-demand water heaters, lighting retrofits and new equipment.

(Hortons, 2010b, p66-67)

Other transportation efficiency improvements were reported, however, did not identify specific savings or goals. These improvements included reducing the maximum speed of trucks and the Tim Horton Children's Foundation buses to $95 \mathrm{~km} / \mathrm{hour}$. THI also implemented an anti-idling policy for all on-site trucks thus reducing fuel consumption and airborne emissions. Moreover, the company also reportedthe installation of in-cab heaters that use engine coolant to heat the truck, improved route selection, and updating a significant portion of the truck fleet (Hortons, 2010b, p68).

\section{(v) Retail Practices}

As a restaurant chain Tim Hortons provides packaging to customers, and acknowledges its role in the distribution of packaging - indicating a struggle between sourcing food and beverage packaging that performs well versus reducing the amount of packaging waste.

The following identifies the company's reported initiatives in its retail operations, as well as field observations. Continuing tits work on diversion programs for paper packaging (hot drink cups), coffee grinds and other food waste eat-in guests are welcome to use reusable cups, plates, bowls, 
and cutlery, which reduce packaging. To encourage a reduction in the use of disposable hot drink cups patrons are offered a 10 cent discount on travel mug refills. During a visit to a Canadian outlet, it appeared that customers were not asked for their preference of cups, nor was signage highly visible regarding the policy.

Annual internal waste audits identify waste streams and opportunities to reduce, reuse and divert waste. Cardboard represented $17 \%$ of the waste from a typical restaurant with a drive thru window (Hortons, 2010b, p63-64). However, the audits did not include the amount that was diverted.

The in-store diversion program (recycling and composting solutions) for paper packaging (i.e. ,hot drink cups) was implemented in Prince Edward Island, and parts of Alberta, British Columbia, Saskatchewan, Manitoba, Ontario, Quebec, New Brunswick, Nova Scotia, and Newfoundland and Labrador. In total over 650 restaurants implemented local waste management and recycling programs. The challenge with these types of programs is the reliance on the public to sort the material into the correct bins, and the availability of municipal waste diversion programs.

More than 320 restaurants now have organic (coffee grinds \& food waste) diversion programs in place. Organic waste accounts for $64 \%$ of the waste from a typical restaurant (Hortons, 2010b, p64), however, here too no goals have been established or reported.

THI is in compliance with stewardship programs and associated fees where such programs exist. The fees paid to these various stewardship organizations subsidize the costs of the municipal recycling programs. In municipalities that do not have stewardship programs, THI participates in deposit-return programs for branded beverage containers (Hortons, 2010b, p63).

\section{(vi) Marketplace/Society}

Tim Hortons is very involved with individual and community 'outreach' programs and support, and it is in this area that they arguably make their biggest positive impact. The following are initiatives, reported by THI and observed in the media, related to the marketplace and society.

An independent verification for the coffee sourcing was implemented to assure compliance with codes of conduct and practices by suppliers through the supply chain (Figure 2), i.e., farmers, producers, organization (co-operatives), intermediary, exporter, importer, and roaster (Hortons, 2011). Moreover, the majority of THI's products were in compliance with guidelines drafted by the Trans Fat Task Force (Hortons; 2010b, p23). The Trans Fat Task Force's final report was presented to the Canadian Ministry of Health (TRANSforming the Food Supply, 2006).

THI also reported sodium content was decreased in soups by an average of $22 \%$ (Hortons; 2010b, p. 18). In 2009, the Globe and Mail newspaper reported, Tim Hortons cut sodium in its cream of broccoli soup by nearly 25 per cent, according to company spokesman David Morelli. This year, the company reduced sodium by 12 per cent in its heart vegetable soup and 20 per cent in its minestrone soup" (Weeks, 2009). In its community outreach initiatives the company has reported that 17,000 disadvantaged children will have participated in Children's Foundation camps or programs by 2013 (Hortons; 2010b, p39). In addition, over 293,000 children 
participated in the Timbits Minor Sports Program in 2010. And, THI has implemented a meaningful, structured and long-term partnership with the Aboriginal communities. Additionally, Tim Hortons has supported the military by donating coffee to soldiers in Kandahar on Christmas Day and Canada Day (July 1). In Kandahar, THI waived all operating costs associated with a franchise, directing the funds to military family support programs through the Canadian Forces Personnel and Family Support Services (CFPFSS) (Hortons; 2010b, p54).

\section{(vii) The Natural Environment}

THI investigates solutions to environmental issues, such as a commitment to research and implementation of initiatives related to waste reduction and diversion, as well as energy and water conservation (Hortons; 2010b, p63). A number of initiatives and accomplishments reported in the THI 2010 Sustainability \& Responsibility Report have been previously noted such as working with packaging vendors, baselines were established as well as a 5\% packaging reduction target within supply chain and manufacturing operations by 2012. Also, over 650 restaurants collect used coffee cups for a diversion program. In 2010, 1,165 restaurants installed three- or four-stream recycling units ensuring that procedures are ready to divert paper packaging (paper cups) as soon as markets are confirmed. In addition, manufacturing facilities, distribution centres and warehouses have implemented energy and water conservation initiatives. However, the results appear to fluctuate, possibly due to the opening of stores and manufacturing facilities.

The company has noted that three restaurants were registered for Leadership in Energy and Environmental Design $\left(\mathrm{LEED}^{\circledR}\right)$ certification in 2010. LEED certification allows THI to showcase its commitment to sustainable principles and environmental stewardship.

From 2008-2010, the fuel efficiency of the truck fleet increased by $2.58 \%$, which includes trucks with distribution fleet and camp buses but appears to excludes truck refrigeration units. Fuel efficiency was maximized with equipment upgrades and attention to driver behaviour (Hortons; 2010b, p62).

Green house gas emissions are another topical area in the media. THI has reported gross greenhouse gas (GHG) emissions of 240,307 tonnes CO2e1. The largest portion of GHG emissions was reported by restaurants $(84.6 \%)$, and the transportation fleet $(10.1 \%)$ (Hortons, 2010b, p67). The drive-thrus provide competitive advantage and are important to the fast food industry. It is generally thought that restaurants equipped with drive-thrus have higher sales than restaurants without one. Drive-thrus are a convenience to patrons and a service to those with limited mobility, individuals with children, senior citizens and patrons in unfamiliar locations late at night or in inclement weather. THI has stated that it will "continue to work with scientific experts to research the impact(s) of drive-thrus" (Hortons, 2010b, p67-68). However, no initiatives were reported to reduce the use of drive-thrus.

\section{$\underline{\text { Implications and lessons learned }}$}

This case is of particular interest because Tim Hortons is not regarded as an environmental leader but its presence is almost ubiquitous in Canada. Visitors to Canada often identify "Tims" as their pick for something uniquely Canadian. The sheer number of outlets with cars idling in drive- 
thrus, especially at breakfast time, and the massive amount of litter generated do not endear the company to even soft environmentalists. A 2005 report cited by the Canadian Broadcasting Corporation claimed that Tim Hortons cups account for $22 \%$ of all the litter in the Canadian province of Nova Scotia (CBC, 2005). The company therefore not only faces a monumental task in reducing its carbon footprint but it also faces a huge public relations challenge.

There are several lessons to be learnt from Tim Hortons' sustainability program. First, the company's goals appear to be too general. For example, it aims to reduce unspecified waste by 5\% by 2012 by establishing baselines and working on packaging reduction. Its other sustainability goals are stated in a similar fashion and greenhouse gases generated are not reported per product. This does not allow for targeting particular aspects of the company's operations. In contrast, Max, the Swedish fast food chain, provides a $\mathrm{CO}_{2}$ menu identifying the impact of each of its products (Svensson and Wagner, 2011). Hence, Tim Hortons' 6\% rise in greenhouse gas emissions in 2010 from 227,315 tons to 240,307 tons (Environmental Leader) offers consumers little guidance on the sources of those emissions. The only detail provided is that just under $85 \%$ of the emissions was from the company's restaurants and $10 \%$ from their distribution fleet. A breakdown of greenhouse gases emitted according to products and operations would offer guidance to environmentally conscious consumers on which products to buy and provide the public with information on the company's progress on sustainability. For example, the drive-thru service at Tim Hortons outlets although a great convenience and perhaps a competitive necessity is a highly visible source of pollution. Does the company not know what proportion of its greenhouse gas emissions is attributable to cars idling in its drive-thrus? If it doesn't then it should address this issue as customers informed on the level of emissions associated with various activities and products would be able to make informed choices in the interest of sustainability.

A second lesson learnt from Tim Hortons' sustainability program is that sustainability and competitiveness are not mutually exclusive. In fact, a sustainability program may be a competitive necessity for companies in highly visible pollution or waste generating businesses.

Third, although the Tim Hortons sustainability program was only recently launched, as far as is known, it was not triggered by any government subsidies or legislation. It appears that the company's sustainability program is driven by institutional forces other than legislation.

Fourth, the limited data available on the impact of the program suggest that it will not succeed unless it becomes a more coordinated comprehensive program. When comparing comments in the Annual Report with the Sustainability Report, the current program runs the risk of being seen as a public relations exercise rather than as a serious effort to help in saving our planet. And, as argued by Svensson and Wagner (2011, p.338), "It is crucial in any corporate effort to create sustainable business models and cycles where the impact on our planet Earth is seriously addressed and minimized. If not, it cannot be seen as a genuine corporate effort towards business sustainability."

Using the framework for a sustainable business model displayed in Figure 1, we sought to use Hart's (1995) well-known typology of a firm's environmental approach. Hart identified three environmental strategies: (1) pollution prevention, which includes minimizing energy consumption, emissions and waste, and is associated with continuous improvement in an effort to reduce costs; (2) product stewardship, which involves minimizing the life-cycle costs of products 
and services, and is associated with stakeholder integration in an effort to preempt competitors; and (3) sustainable development, which involves minimizing the environmental burden of firm growth, and is associated with increased short-term costs and a corresponding loss in profitability, but the potential for stronger future performance relative to competitors.

To classify THI's sustainable business approach into one of Hart's three environmental approaches, we examined each component of the framework in Figure 1 individually and ranked it from 1-3 (where 1 = pollution prevention, 2 = product stewardship, 3 = sustainable development). In all cases, THI never achieved a ranking higher than 1 . Thus, we can confidently place THI within the pollution prevention categorization.

Thus despite THI's repeated message that sustainability was embedded through-out the organization, our investigation revealed that this was done primarily to drive competitiveness and enhance profitability. If, however, sustainability and profitability can be achieved simultaneously as many have argued (e.g., Makower, 2009; Savitz \& Weber, 2006; Dos Santos,2011); Hogevold, 2011), there is nothing inherently wrong with this approach. Yet, in the case of THI, it seems to have resulted in a relatively short-sighted and limited adoption rather than a systematic approach to corporate sustainability such as that advocated by Asif et al. (2011).

\section{$\underline{\text { Conclusion }}$}

This paper documented the initial efforts of a large Canadian fast food company to address sustainability in a comprehensive fashion. It is too early to make any pronouncements on the impact of the program but its current strengths and weaknesses are apparent. Foremost among the latter is a lack of specificity, without which it would be difficult to assess Tim Hortons' progress in what is clearly an important initiative. The company would be well advised to track its carbon footprint in a more detailed fashion so that the next time one joins the line at a Tims' drive-thru for example, they would be conscious of how that may affect rising ocean levels and ultimately the health of our planet. 


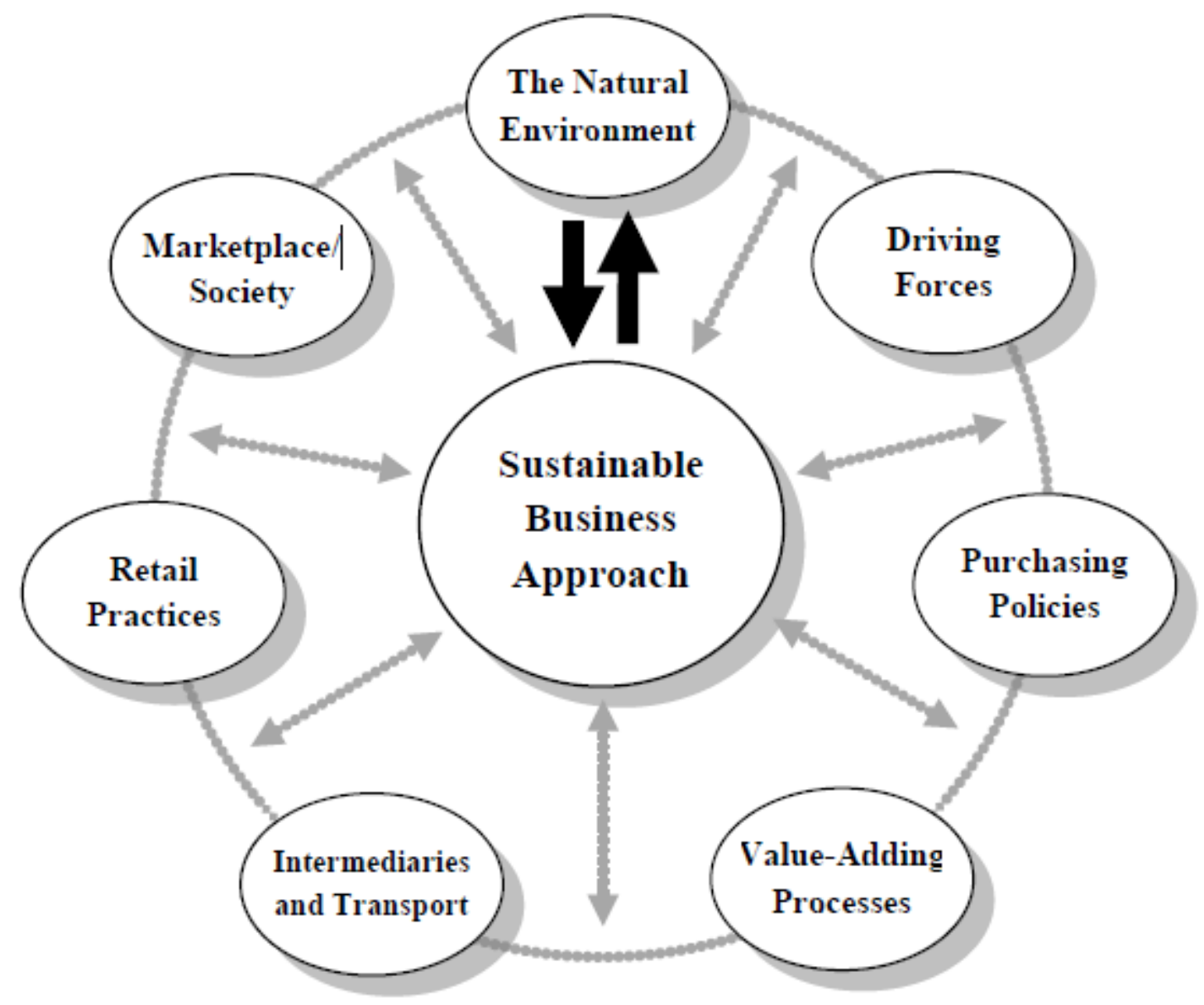

Figure 1: A Framework of a Sustainable Business Model.

\section{$\underline{\text { References }}$}

Asif, M., Searcy, C., Zutshi, A., \& Ahmad,N. (2011), “An integrated management systems approach to corporate sustainability," European Business Review, Vol. 23 No 4, pp. 353-367.

CBC (2005), “Tim Hortons launches anti-litter campaign”. Retrieved May 11, 2011 from the World Wide Web: http://www.cbc.ca

Bansal, P., \& Roth, K. (2000), Why companies go green: A model of ecological responsiveness," Academy of Management Journal, 43(4): 717-736.

Dos Santos,M. (2011), "Minimizing the business impact on the natural environment: A case study of Woolworths South Africa," European Business Review, Vol. 23 No 4, pp. 384391.

Environmental Leader (2011), "Tim Hortons says all environmental goals on track, in first sustainability report." Retrieved May 11, 2011 from the World Wide Web: http://www.environmentalleader.com 
Gore, A. (2006), An Inconvenient Truth: The Planetary Emergency of Global Warming and What We Can Do About It. Rodale, New York.

Hart, S. (1995), A natural-resource- based view of the firm. Academy of Management Review, 20(4): 986-1014.

Hogevold, N. (2011), “A corporate effort towards a sustainable business model: A case study from the Norwegian furniture industry," European Business Review, Vol. 23 No 4, pp. 392-400.

Hortons, Tim (2010). Annual Report 2010. Retrieved April 2011, from the World Wide Web: http://annualreport.timhortons.com/

Hortons, T. (2010b). The 2010 Sustainability and Responsibility Report. Retrieved April 2011, from the World Wide Web: http://sustainabilityreport.timhortons.com/

Hortons, T. (2011). Supply Chain: Our Commitments. Retrieved April 2011, from the World Wide Web:http://sustainabilityreport.timhortons.com/planet_supply_chain.html

Hortons, T. (2011b). Environmental Stewardship: Our Commitments. Retrieved April 2011, from the World Wide Web: http://sustainabilityreport.timhortons.com/planet_env_steward.html

Mahler, D. (2007), “The sustainable supply chain”, Supply Chain Management Review, Nov., 59-60.

Makower, J. (2009), Strategies for the Green Economy: Opportunities and Challenges in the New World of Business, New York, McGraw-Hill.

Margolis, J. D., \& Walsh, J. P. (2003), Misery loves companies: Rethinking social initiatives by business. Administrative Science Quarterly, 48(2): 268-305.

Orlitzky, M., Schmidt, F. L., \& Rynes, S. L. (2003), Corporate social and financial performance: A meta-analysis. Organization Studies, 24(3): 403-441.

Pacala, S., \& Socolow, R. (2004), Stabilization wedges: Solving the climate problem for the next 50 years with current technologies. Science, 305(5686): 968-972.

Post, J. E., Preston, L.E. and Sach, S. (2002), "Managing the extended entreprise: The new stakeholder view," California Management Review, Vol. 45, pp. 5-28.

Russo, M. V., \& Fouts, P. A. (1997), A resource-based perspective on corporate environmental performance and profitability. Academy of Management Journal, 40(3): 534-559.

Savitz, A.W. and Weber, K. (2006), The Triple Bottom Line: How Today's Best-Run Companies are Achieving Economic, Social, and Environmental Success-and How You Can Too, San Francisco: Jossey-Bass.

Svensson, G. and Wagner, B. (2011a), “A Process Directed towards Sustainable Business 
Operations and a Model for Improving the GWP-Footprint (CO2e) on Earth", Management of Environmental Quality (Forthcoming Issue).

Svensson, G. and Wagner, B. (2011b), "Transformative business sustainability: Multi-layer model and network of e-footprint sources”, European Business Review, Vol. 23 No. 4, 2011, pp. 334-352.

TRANSforming the Food Supply (2006). Final report of the Trans Fat Task Force, co-chaired by Health Canada and the Heart and Stroke Foundation of Canada. Retrieved June 2011, from the World Wide Web: http://hc-sc.gc.ca/fn-an/alt_formats/hpfbdgpsa/pdf/nutrition/tf-gt_rep-rap-eng.pdf

Wagner, B. and Svensson, G. (2010), “Sustainable Supply Chain Practices: Research Propositions for the Future", International Journal of Logistics Economics and Globalisation, Vol. 2, Nr. 2, pp. 176-185.

Weeks, C. (2009, July 29). Salt, Hard to Shake: the taste of things to come. The Globe and Mail.

World Commission on Environment and Development, (1987), Our Common Future Oxford: Oxford University Press. 